\title{
Articles
}

\section{Literacy Engagement in Multilingual and Multicultural Learning Spaces}

\section{Theodora Kapoyannis}

This article presents qualitative findings from a larger design-based research doctoral study in which I examined the impact of a curricular innovation to challenge the monolingual and monocultural norms of literacy practices and to be responsive to the linguistic and cultural landscape of 21st century classrooms. I collaborated with 11 university preservice teachers and 28 English language learners (ELLs) in Grades 2 and 3 to design and implement a literacy intervention, called the Name Jar Project, focused on cultivating literacy engagement. I used constant comparison analysis to analyze data sources, which included field notes, student artifacts, and preservice teachers' reflections. This article documents the positive impact of the intervention in supporting the students' linguistic and cultural needs, affirming their identities, and bolstering their vocabulary development.

Cet article présente les constatations qualitatives d'une étude de recherche de doctorat plus importante conforme au modèle méthodologique de recherche-design (design-based research, ou DBR) dans laquelle j'ai examiné l'impact d'une innovation pédagogique conçue pour remettre en cause les normes unilingues et uniculturelles des pratiques de littératie et pour permettre à l'enseignement de s'adapter au paysage linguistique et culturel des salles de classe du 21e siècle. J'ai collaboré avec 11 enseignantes et enseignants universitaires en formation et 28 apprenantes et apprenants de la langue anglaise (English language learners, ou ELLs) de 2e et 3e année afin de concevoir et de mettre en cuvre une intervention en matière de litératie, baptisée Name Jar Project, centrée sur une démarche favorable à la culture de la littératie. J'ai constamment eu recours à des techniques d'analyse comparative pour analyser les sources de données, lesquelles comprenaient des notes, des artefacts associés au prénom de chaque élève et des réflexions d'enseignantes et enseignants en formation. Cet article documente l'impact positif de l'intervention sur la réponse aux besoins linguistiques et culturels des élèves, l'affirmation de leur identité et la stimulation du développement de leur vocabulaire.

KEYWORDS: English language learners, ELLs, literacy engagement, multilingualism, vocabulary development, multiliteracies, identity texts, design-based research, DBR

TESL CANADA JOURNAL/REVUE TESL DU CANADA 


\section{Introduction}

Classrooms in the 21st century are changing rapidly in response to Canada's demographic profile. According to Statistics Canada's (2017) latest report on immigration, nearly one in two Canadians could be an immigrant or a child of an immigrant by 2036, and more than $30 \%$ of the Canadian population would have a mother tongue other than English and French. These national immigration patterns are reflected in Alberta's diverse learning environments. An increasing number of younger arriving immigrants and Canadianborn children who speak a language other than English at home make up a significant portion of K-12 classrooms (Alberta Education, 2012). In the large urban board where this study took place, one quarter of the total student population is of this linguistic profile.

I use the phrase English language learners (ELLs) to refer to learners who do not speak English as their first language. This designation includes both foreign- and Canadian-born students and aligns with the current terminology in provincial programming (Alberta Education, 2012). I refer to multilingualism and multiculturalism as the presence of several languages and cultures, respectively, in a given geographical or social context (Coste, Moore, \& Zarate, 2009), and to Banks and Banks' (1997) definition of culture as the "values, symbols, interpretations, and perspectives that distinguish people from one another" (p. 8).

\section{The Research Problem}

Children come to school with a foundation in knowledge and learning from their home and their communities. Development and learning begin in the native language, and through the first language, children begin to make meaning in their lives. For young ELLs, "The complexities involved with literacy and language development are compounded by the fact that they must be achieved in a language other than their native language and often before they are literate in that language" (Teaching English to Speakers of Other Languages, 2010, p. 3).

It has been well documented that many ELLs face challenges in achieving high literacy levels (August \& Hakuta, 1998; Collier, 1995a, 1995b; Cummins, 2000; Roessingh, 2018; Roessingh \& Kover, 2003). As ELLs move through the higher grades, they are required to read and understand increasingly complex texts (Linan-Thompson \& Vaughn, 2007; Roessingh \& Elgie, 2009). This complexity is inherent in academic language, which is distinct from social, conversational language (Cummins, 1981; McLaughlin, 1992; Roessingh, 2018): Academic language is more formal and abstract, with fewer contextual clues to support students' understanding. It is characterized by difficult curricular concepts expressed using low-frequency and technical vocabulary 
embedded in text with sophisticated grammatical structures (Cummins, 2011a; Cummins \& Man, 2007; Roessingh, 2018).

Many educators also feel challenged in being responsive to the linguistic and cultural diversity in their classrooms (Alberta Teachers' Association, 2014; Goldenberg, 2013; Howard Research \& Management Consulting, 2006, 2009; International Literacy Association, 2017; Roessingh, 2011). To address the literacy and language needs of young ELLs, it is necessary to continue to reflect on the role of first language and culture and how teachers respect the multiple languages and varying cultural experiences that students, families, and communities bring into the classroom (Chow \& Cummins, 2003; Cummins, 2011a, 2011b; Cummins \& Early, 2011; Early \& Yeung, 2009; Escamilla, 2009; Goldenberg, 2013; Naqvi, McKeough, Thorne, \& Pfitscher, 2012; Roessingh, 2011; Schecter \& Cummins, 2003; Taylor, 2010; Toohey \& Dagenais, 2010).

In this regard, the current study calls for educators to think about early literacy practices beyond a monolingual and monocultural habitus. Monolingual and monocultural habitus refers to "the beliefs, basic concepts, [and] common-sense patterns as elements of the practical professional knowledge or the practical professional behaviour of teachers" (Gogolin, 2002, p. 132). Literacy is, instead, defined through a multiliteracies approach (Cope \& Kalantzis, 2009; Gee, 1996; Pahl \& Rowsell, 2010; Street, 2003), where multiple modes of meaning-making and communication are emphasized, extending the traditional views of reading and writing to include linguistic, visual, audio, and performative modalities. Escamilla (2009) captured the need for society to think outside of a monolingual and monocultural habitus by discussing bilingualism as the global norm. Benson (2013) also argued that a monolingual habitus

causes us [educators] to view a learner as deficient if s/he does not speak the dominant language used for instruction when we should recognize and make use of all the linguistic, cultural and experiential resources that $\mathrm{s} /$ he brings with her to the classroom. (p. 285)

This position was reinforced by Ntelioglou, Fannin, Montanera, and Cummins (2014), who stated that multiple language practices of students and communities have been slow to be recognized by Canadian schools.

\section{Aims of the Study}

To embrace the multiple languages and cultural experiences of ELLs and to support their academic language, I collaborated with 11 university preservice teachers and 28 ELLs in Grades 2 and 3 to design and implement a literacy intervention we referred to as the Name Jar Project. The literacy intervention was part of a larger design-based research (DBR) doctoral study that inquired into the primary research question: How can educators cultivate lit- 
eracy engagement to support English language development? I explored literacy engagement through the Literacy Engagement Framework (Cummins \& Early, 2011), which emphasizes that active engagement with literacy will be enhanced when (a) students' prior knowledge is activated, (b) their ability to understand and use academic language is supported through specific instructional strategies, (c) their identities are affirmed, and (d) their knowledge of and control over language is extended across the curriculum.

I used the storybook The Name Jar (Choi, 2001) in the literacy intervention to anchor sequenced and linked literacy tasks that resulted in the creation of identity texts about how the ELLs made meaning of their names. Identity texts focus on embracing the students' first language and culture through a learning experience in which students invest their identities into their text creation. Identity texts can be multimodal, including written, spoken, visual, and dramatic, or a combination of arrangements (Cummins \& Early, 2011; Cummins, Hu, Markus, \& Montero, 2015; Stille \& Prasad, 2015). My intent was to provide a learning space where the children were invested and empowered in conveying, through language, their sense of how their name contributes to their unfolding quest to know themselves as members of the larger Canadian multicultural, multilingual reality.

In my doctoral study, I took a two-pronged approach to the research design, examining the impact of the intervention on both meeting the needs of the young ELLs and supporting the preservice teachers' emerging practice. This article focuses on the former and presents key findings to respond to two questions: How did the designed literacy intervention support the students' academic language? What impact did the designed literacy intervention have on affirming students' identity?

\section{Theoretical Lenses Framing the Study}

In this section, I describe how a multiliteracies approach to literacy teaching, the Literacy Engagement Framework (Cummins \& Early, 2011), and extending vocabulary development framed the study and informed the design of the literacy intervention.

\section{Multiliteracies Approach to Literacy Teaching}

Literacy teaching through a multiliteracies approach goes beyond skills and competence: Meaning-making is active, dynamic, and process oriented, and students are encouraged to use multiple modes of communication (Cope \& Kalantzis, 2009). In the Name Jar Project, teachers invited the students to choose a name artifact ("name treasure," as the ELLs called them) to make relevant and meaningful connections to their names and who they are. These artifacts were, for the most part, objects that the students brought from home and shared within small group configurations. There is power in sharing 
cultural artifacts to develop home-school connections and for students to share stories about their families and communities (Pahl \& Rowsell, 2011; Roessingh, 2011). The ELLs used the name artifacts to invest their identities in creating identity texts (Cummins \& Early, 2011; Cummins et al., 2015; Stille $\&$ Prasad, 2015) to inquire into how they made meaning of their names.

I refer to the terms identity and identity investment through a sociocultural conception of teaching and learning where learners are active beings whose reality is constructed through meaningful social activity (Gordon, 2009). Within this notion, identities are viewed as multiple, dynamic, and shifting across time and space as students make sense of how they understand their relationship to the world (Norton, 2006). The connection between identity and language learning is co-constructed within sociocultural relationships that are influenced by how power relations operate in broader society (Cummins, 2000). In this respect, Cummins (1996) wrote,

Culturally diverse students are disempowered educationally in very much the same way that their communities have been disempowered in their interactions with societal institutions. A genuine commitment in helping all students succeed requires a willingness on the part of educators, individually and collectively, to challenge aspects of the power structure in the wider society. (p. iii)

The construct of identity investment focuses on the language learner's investment in the target language practices of the classroom. The language learner is seen to have a complex identity that is influenced by patterns of social interaction and societal pattern relations (Norton, 2013). In the context of this research study, identity texts "represent an instructional tool that transforms the interpersonal space within the classroom to enable students (particularly those from marginalized social groups) to develop and showcase identities of competence linked to literacy and academic work generally" (Cummins \& Early, 2011, p. 32). The identity texts then "hold a mirror up to the students in which their identities are reflected back in a positive manner" (Cummins \& Early, 2011, p. 3).

\section{The Literacy Engagement Framework}

For the literacy intervention, I drew on the instructional dimensions of the Literacy Engagement Framework (Cummins \& Early, 2011) to enable ELLs to engage actively with literacy from an early stage of English language development. Access to print resources and extensive reading play a causal role in students' literacy achievement through opportunities to broaden vocabulary knowledge and develop strong reading comprehension skills (Cummins, 2011a; Guthrie, 2004; Krashen, 1981; Lindsay, 2010). This framework has been influenced by Guthrie's (2004) work on literacy engagement in the context of reading for all learners. Guthrie identified engaged reading as frequent, 
focused, and socially interactive. It emphasizes intrinsic motivations that contribute to literacy engagement, such as curiosity, involvement, preference for challenge, and a desire to read. Guthrie defined engagement and achievement as a reciprocal process: Students' sense of identity and self-confidence develops, and they begin to see themselves as learners and thinkers.

\section{Extending Vocabulary Development}

To develop academic language across the curriculum, I had an intentional and purposeful focus on supporting and extending students' vocabulary development. Roessingh and Elgie (2009) discussed that providing additional supports in the younger grades for vocabulary development is essential in supporting ELLs' literacy and language skills. Indeed, "early identification and intervention may hold the key to changing the slope of the educational trajectory, especially in the $\mathrm{K}$-grade 2 range where there might be potential for accelerated acquisition of language and early literacy skills" (Roessingh \& Elgie, 2009, p. 27). Their statement has been supported by literature identifying the critical role of a well-developed vocabulary for all learners beginning in Grade 3 (August, Carlo, Dressler, \& Snow, 2005; Dickinson, Flushman, \& Freiberg, 2009). There is continued need to support young ELLs with vocabulary development within early literacy practices (Biemiller, 2004; Hart \& Risley, 1995; Horst, 2010; Roessingh, 2018; Roessingh \& Douglas, 2013) to improve their academic language.

\section{Methodology and Design of the Literacy Intervention}

\section{Design-Based Research}

Using DBR principles (Amiel \& Reeves, 2008; Anderson \& Shattuck, 2012; Brown, 1992), I worked collaboratively with preservice teachers (the ELLs' "university buddies") to design and implement the literacy intervention. DBR emphasizes a pragmatic orientation involving a choice of mixed methods and a variety of research tools to respond to complex and authentic educational problems (Brown, 1992). This methodology takes an interventionist approach that is collaborative, grounded in the literature, and shaped by field testing and participant expertise (McKenney \& Reeves, 2012).

Using the curricular framework Roessingh (2010a) outlined in Learning by Design, the first-year preservice teachers delivered the literacy intervention in a progression of 10 lessons over 20 literacy sessions in small group configurations (see Appendix A for the curricular framework). Based on the relevant literature, and with input from the preservice teachers, we designed and implemented the intervention based on principles and strategies to cultivate literacy engagement and support English language development: the use of culturally relevant text as an anchor, determination of target vocabu- 
lary, and instructional strategies to support vocabulary development in the literacy sessions (see Table 1).

Table 1

Design Principles and Implementation Strategies of the Literacy Intervention

\begin{tabular}{ll}
\hline Design principles guiding the intervention & Strategies to support implementation \\
\hline $\begin{array}{l}\text { Provide intentional scaffolding and modelling } \\
\text { opportunities for English language development. }\end{array}$ & $\begin{array}{l}\text { Use Learning by Design curricular framework } \\
\text { (Roessingh, 2010a) for lesson development, additional } \\
\text { scaffolding, and modelling resources for preservice } \\
\text { teachers to use on D2L. }\end{array}$ \\
$\begin{array}{ll}\text { Promote and value use of first language and culture. } & \text { Encourage first language and culture through dual } \\
& \text { language opportunities, shared reading of culturally } \\
& \text { relevant text, name artifacts, and creation of identity } \\
\text { texts. } & \text { Extend academic language by developing and } \\
\text { Provide opportunities for extension of academic } & \text { recycling tiered vocabulary, using curricular } \\
\text { language. } & \text { connections, and conducting vocabulary development } \\
\text { tasks with multiple exposures to new words. }\end{array}$ \\
$\begin{array}{ll}\text { Support practitioners through experiential and situated } \\
\text { learning opportunities. }\end{array}$ & $\begin{array}{l}\text { Reflect on literacy sessions; use D2L to provide } \\
\text { resources and models to support preservice teachers. }\end{array}$ \\
\hline Note. D2L (Desire2Learn) is an online learning platform.
\end{tabular}

The use of culturally relevant text as an anchor. The Name Jar (Choi, 2001) is a culturally relevant book we used during the intervention to anchor the literacy tasks in the literacy sessions.

It's a new country, a new town, and a new school for Unhei. So what about a new name? Having just arrived from Korea with her family, Unhei is anxious about making friends and worried that no one will be able to pronounce her name. Instead of introducing herself on the first day of school, she decides to pick a new name. The only problem is that she doesn't know what name to choose! (Choi, 2001, back cover)

Culturally relevant texts provide ELLs with the opportunity to engage with content that connects to their cultural backgrounds (Freeman \& Freeman, 2004); such texts can include dual-language books written in both English and the students' first language to reflect their language and culture. Each child was given a copy of The Name Jar to read during the literacy sessions. Students also took the books home to share with their parents, emphasizing the home literacy connection in the project.

The use of this culturally relevant text allowed students to focus on curricular connections to the Alberta Grade 2/3 program of studies, which included concepts of identity, culture, relationships, and feelings. Through the book and the literacy tasks, students were encouraged to inquire into differ- 
ent critical questions about how they make meaning of their names. These questions included (but were not limited to) the following:

- Do you know how you were named?

- Does your name have a certain meaning?

- Do you know your name in your first language?

- Would you ever change your name and why?

- Would you want or let anyone else change your name and why?

The preservice teachers and I communicated with parents about this project from the onset. An integral part of the home-school connection was asking the parents to select a name artifact with their children. The preservice teachers discussed and modelled the concept of the name artifact in the literacy sessions. They brought their own name treasures to share with the students and explained why the chosen treasure was significant and how it connected to their names. Teachers emphasized that the name treasure did not have to be an actual object but could take other forms, such as photos, student-created illustrations, or verbal descriptions. The name artifacts the students shared were diverse and varied. Examples included baby and family photos, precious jewelry given to them at birth, and gifts they had been given before leaving their home countries. The ELLs shared their name treasures in their small groups and described how the chosen name artifacts were significant and connected to their names.

Target vocabulary for the literacy intervention. Another important dimension included in the curricular planning was identifying the target vocabulary and instructional strategies to support vocabulary development in the literacy sessions. Although The Name Jar (Choi, 2001) was a relevant and age-appropriate anchor book, the narrative text needed to be supplemented with literacy tasks, resources, and materials that would extend students' academic language, as outlined in the curricular framework (see Appendix A). Informed by Beck, McKeown, and Kucan's $(2002,2008)$ work on a threetiered system of vocabulary, we framed the target vocabulary within three tiers (see Figure 1). Tier 1 words are basic words that can be learned from context, such as sight words, nouns, verbs, and adjectives. Tier 2 words include generic academic vocabulary that travels across curricular boundaries, such as analyze, obtain, provide, dispose, and investigate. Many of these words have Greek and Latin roots and are important to reading comprehension. Tier 3 words, such as photosynthesis, are discipline-specific, with more transparent meanings. Moving beyond Tier 1 and Tier 3 vocabulary to focus more on Tier 2 vocabulary was reinforced in the literature as a critical element in task design to support ELLs in extending their academic language (Beck et al., 2002, 2008; Cummins, 2011a; Roessingh, 2010b). 
Tier 3. Content words to know: custom, belief, habit, tradition, origin, community, individual, culture, unique, distinct, immigrant, relative, inherit, unique, bracelet, jewelry, clothing, braid, scar, freckle, pronounce

Tier 2. Next words to know: confuse, suggest, memory, favorite, fair, connect, include, adapt, remain, adjust, ordinary, celebrate, common, divide, equal, manage, secure, possessions, contribute, naturally, process, accept, respect, prefer, value, worth, describe, reject, select

Tier 1. Words to know: happy, sad, glad, lonely, surprised, proud, upset, worry, anxious, excited, afraid, disappointed, useless, stupid, shy, embarrassed, angry, curious, welcome, pick/choose, decide, free, tell/say, reply, explain, invite, exclaim, realize, special, precious, use, family, parents, mother/father, daughter, brother/son, aunt, change, arrive, belonging

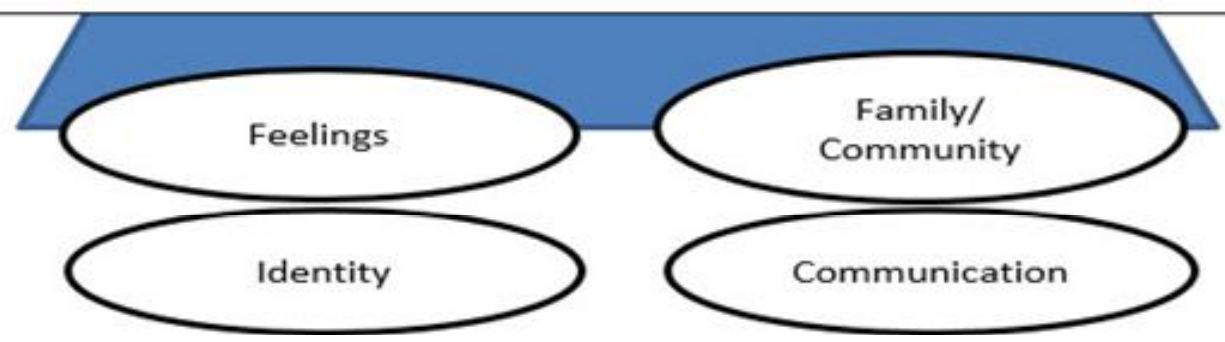

Figure 1. Vocabulary pyramid illustrating the tiered vocabulary and vocabulary clusters connected to the program of studies targeted for the intervention.

Instructional strategies to support and extend vocabulary development. Each lesson had specific target words based on the lesson objectives. Preservice teachers introduced and developed these words through various learning tasks, as captured in the curricular framework (see Appendix A). The preservice teachers had access to the online Desire to Learn (D2L) site, which housed additional ideas, materials, and resources for them to use and personalize the experience for their groups. D2L provided an effective way for the preservice teachers and me to stay connected and communicate about the project.

Every lesson focused on not only introducing the new vocabulary in the context of the project, but also recycling the vocabulary through different instructional strategies (see Appendix B). Part of this intentional recycling of vocabulary was a gaming aspect that we referred to as "word play." Each student had his or her own set of word play cards to individualize and customize. The students were encouraged to design their own cards and associate the words with pictures, first language translations, examples, definitions, and other ways to make connections to the target words. Students were in- 
vited to create word play cards for other words that they made connections to throughout the project. These words were incidental to the project but important to the overall vocabulary development process. During the lessons, the preservice teachers and/or the students initiated games to play with their cards. The students were invited to take these cards home to share with their parents, practice their words, and challenge themselves to include a first language translation of the target words. Figure 2 shows an exemplar of the word play cards translated in English and Spanish.

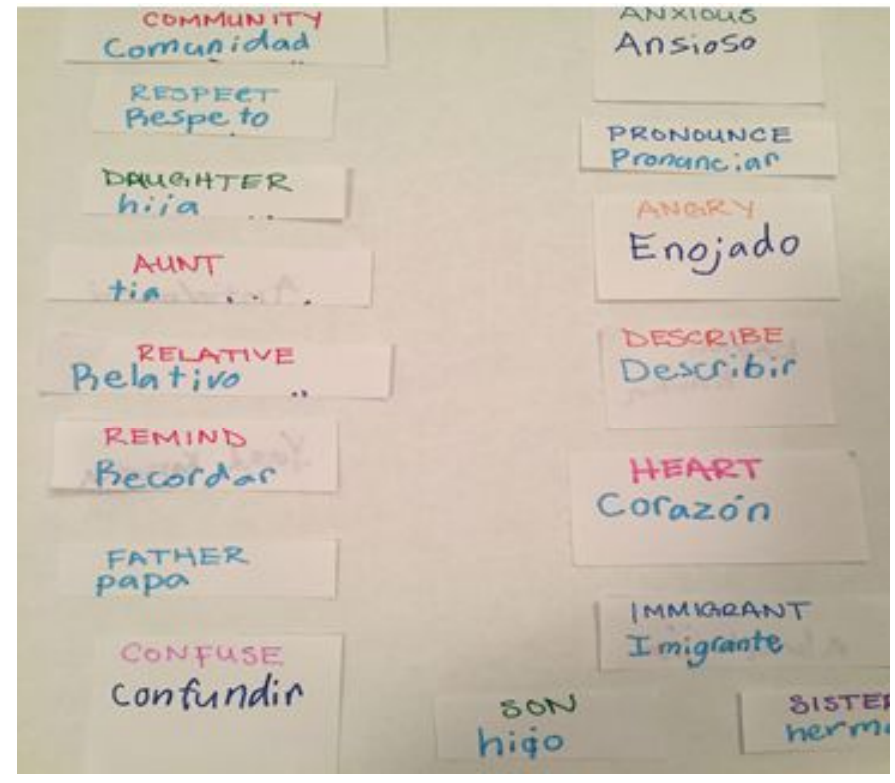

Figure 2. Sample of word play cards in English and Spanish.

\section{Setting and Participants}

The research took place within a linguistically and culturally diverse elementary school setting in Alberta. The focus was to work with a purposive sample of ELLs in Grades 2 and 3 with an intermediate level of English language proficiency according to the ESL provincial benchmarks (Alberta Education, 2012). The ESL benchmarks are an informal criterion-based assessment designed to assess language proficiency in the classroom context. In total, 28 young ELLs worked in small groups with 11 selected first-year preservice teachers to implement the first iteration of this literacy intervention and to provide insight into the inquiry.

The preservice teachers were recruited from the first-year Bachelor of Education cohort at a local university who had volunteered to participate in a service learning project to support ELLs. This service learning project was one of many opportunities that this university has offered to undergraduate students to gain more experience in working in diverse settings. The preservice teachers had identified few informal and formal learning opportunities in working with ELLs and were keen to participate in the project to deepen 
their understanding of how to support linguistic and cultural diversity in their future classrooms. Following ethical guidelines, informed consent was obtained from all participants.

\section{Data Collection Methods and Analysis}

A total of 20 literacy sessions took place twice a week for $60 \mathrm{~min}$ per session. These literacy sessions were part of a 6-month inquiry that allowed for the literacy intervention to be designed and implemented as well as to collect and analyze a rich assortment of data sources.

Data sources included my field notes as participant observer as I situated myself at the research site with the staff, ELLs, and the preservice teachers. I wrote field notes as I observed the literacy sessions in the small group configurations, which provided a source of qualitative insight to determine the impact of the literacy intervention. The preservice teachers also wrote notes on each of the literacy sessions with their observations and reflections on the strengths and areas of improvement for the intervention. I collected these written reflections throughout the project, which became secondary data for analysis. I also collected and analyzed samples of students' work, including the ELLs' identity texts. The collection and analysis of these three data sources allowed me to triangulate the data.

Using constant comparison analysis (Onwuegbuzie, Dickinson, Leech, \& Zoran, 2009; Parry, 2004; Strauss \& Corbin, 1998), I followed a three-stage analysis process of open, axial, and selective coding to analyze these data. Themes emerged to determine the positive impact the literacy intervention had on supporting the linguistic and cultural needs of the ELLs. In constant comparison analysis, a point of saturation is reached at which no new information or understanding are generated. Findings are grounded in the data set, and the themes that are identified can be illustrated though multiple data fragments, such as quotes (Lincoln \& Guba, 1985).

\section{Findings}

In anaysis of the data to determine the impact the designed intervention had on the young ELLs, two key themes emerged. First, the data revealed how the use of the name artifacts and identity texts affirmed the students' identities by providing a learning space where students could proudly share stories about their families, languages, and cultures. Second, the ELLs used and applied the vocabulary and concepts targeted in the literacy intervention to create their identity texts, which positively supported their vocabulary development.

I provide three representative learner exemplars of the students' identity texts, as well as participant quotes from the preservice teachers and young ELLs to illustrate the positive impact the intervention had on affirming the 
students' identities while incorporating the target vocabulary in meaningful ways. All names used are pseudonyms, and quoted material has been kept as close to the original as possible to preserve the participants' voices. I have boldfaced the target vocabulary from the literacy intervention in the students' identity text transcriptions. The first exemplar is a transcription of an identity text from Israa, a Grade 3 ELL born in Canada (see Figures 3 and 4).

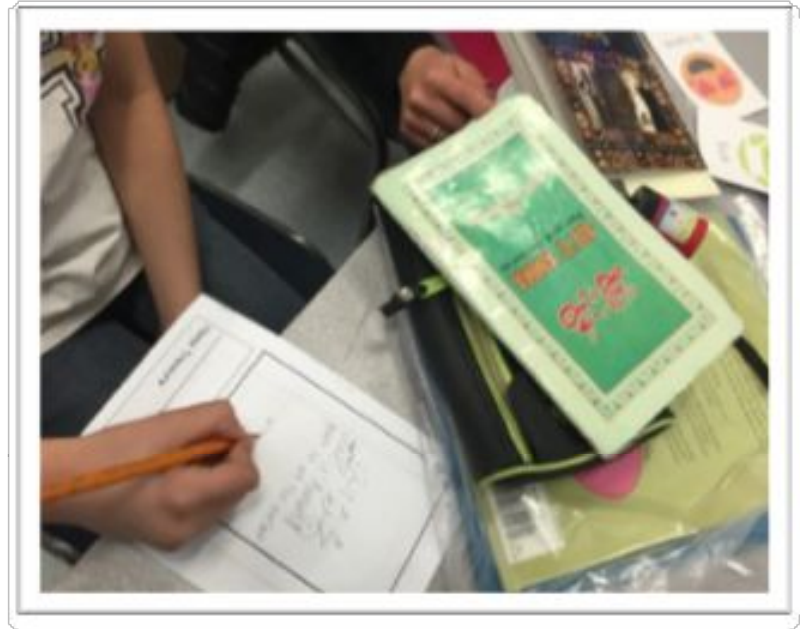

Figure 3. Sample of an English language learner's name artifact.

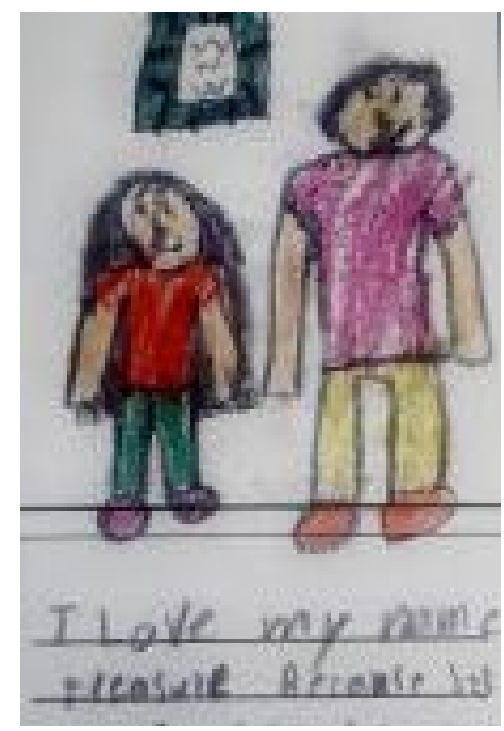

Figure 4. Sample writing from identity text.

Israa chose to share the Quran to make meaning of her name:

My name treasure is the Quran book. I read it on Saturdays because on Saturday I have Islamic school. It's hard to read but I still like it. It was given to me by my dad. My dad got the book from my grandmother and then he gave it to me. I wanted to share it because it's a book from God so we can learn more about Islam. I love my treasure because its connected to my family and it connects to me and who 
I am. It makes me feel good because I feel like it has a connection to my family which means a lot to me. It is a book from God/Allah. It is important to me because faith means a lot to me. My name means Read.

Author's Page: I speak English and Urdu at home. I'm learning Arabic here. I think I'm unique because I'm learning three languages. (Israa)

Israa explored through the literacy sessions that her name meant "read," and she chose the Quran to share as a significant text she reads outside of school. She connected her name to her family, the languages she speaks, and the importance of religion to her life. She used many of the target words in the intervention, including family, unique, and important, and different forms of the word connect, including connected, connects, and connection. Israa was born in Canada and identified with speaking English and Urdu at home while attending heritage language school on Saturdays to learn Arabic. She associated how the Quran connects her to her family and the importance of that connection to who she is. She also drew on the importance of faith and religion in her life to describe the relevance of the Quran in her identity text.

The second student exemplar is from a Canadian-born Grade 3 student, Rizal. His university buddy stated in her reflections that he was consistently absent from school and had missed many of the lessons; she found it difficult to assess his understanding and catch him up with the literacy sessions. When it came time to share his name artifact, Rizal said that he did not have one and that he was not going to bring one. We reinforced that the name treasure did not have to be an actual object; students could choose to share in different ways. Of interest was that this student wanted to complete the name artifact lesson and wanted to represent his name treasure visually instead of bringing an object. Through support and encouragement from his university buddy, Rizal chose to capture his name artifact visually (see Figure 5).

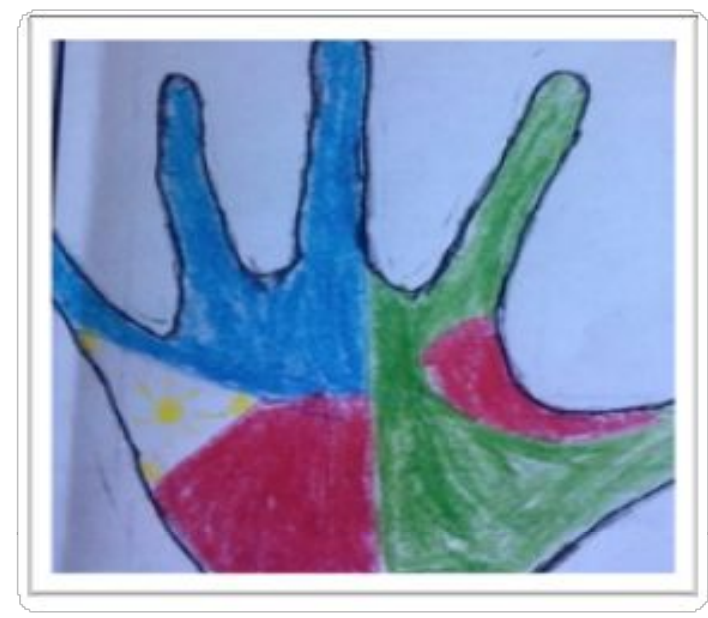

Figure 5. Sample of an English language learner's visual name artifact. 
Rizal struggled with writing down his ideas and needed a great deal of support and scaffolding. Although he had difficulty writing about his name artifact, he could share orally with his peers and was keen to participate and share his treasure through his visual. In his identity text, he chose to describe his name artifact in the following way:

My name treasure is my hand and a picture with two flags on it and my baby hand in the middle. The Bengal flag and Filipino flag, where my mom and dad are from. I wanted to share it because it is part of my history and also tells about peace. It means stopping wars. My name treasure was passed down from my grandpa. My grandpa also is nice and fun. It was given to me by my mom. My mom is nice, helpful, smart. It makes me feel happy because it's my history. It also tells about me and who I am.

Author's Page: My name means River to Paradise, and I was born in Calgary. (Rizal)

Rizal's identity text is powerful in terms of how he chose to share his name artifact and how he made meaning of his name. His artifact shows an outline of his hand with a depiction of his baby hand within that outline. He identifies with the two flags of his parents' countries of origin, and he associates the two flags as a peaceful coming together, which is part of his history. His baby hand shows how he has connected his name given to him at birth and how it has been passed down by his grandfather. He used feelings words targeted through the intervention such as nice, helpful, and smart to describe his mother, who gave him his name. He chose to share with his group members that his parents were divorced, and the group decided to add the word divorce to their word play cards. Rizal also identified with English as the only language spoken at home and with his family. His learner profile reinforces the multilayered nature of students' identities and the diversity that exists within ELL profiles.

The third exemplar is from a Grade 3 student born in Mexico, Sabina, who chose to share a doll given to her by her grandmother and illustrate it in her identity text (see Figure 6). 

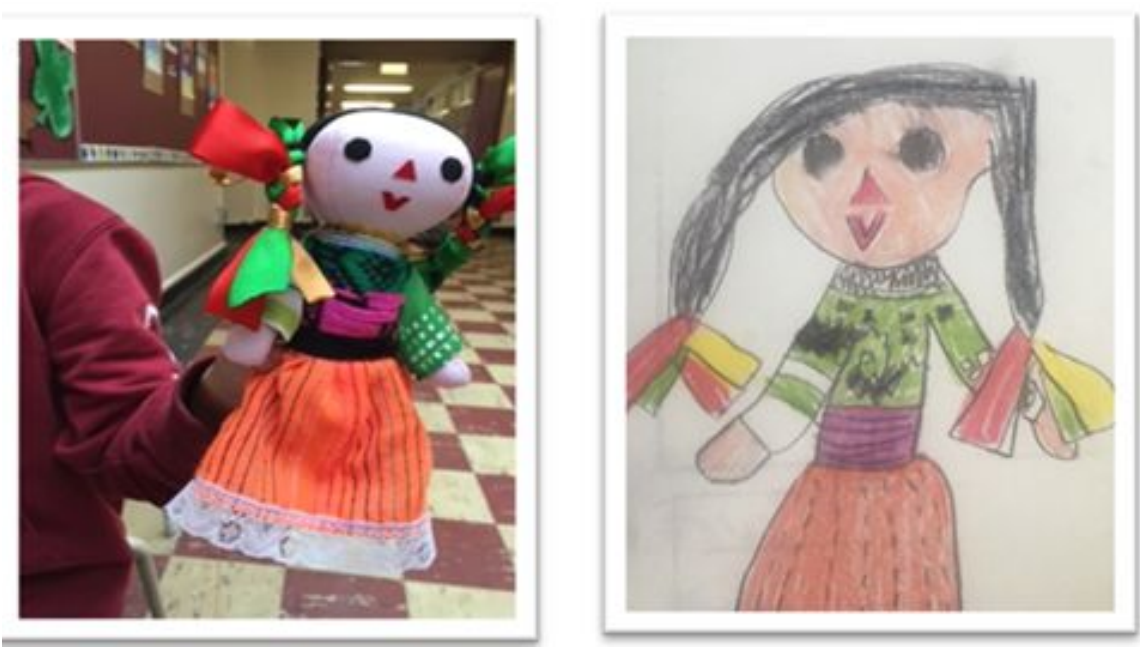

Figure 6. Student sample of a name artifact and an illustration from an identity text.

Figure 7 captures a sample of how Sabina used the target vocabulary in her identity text.

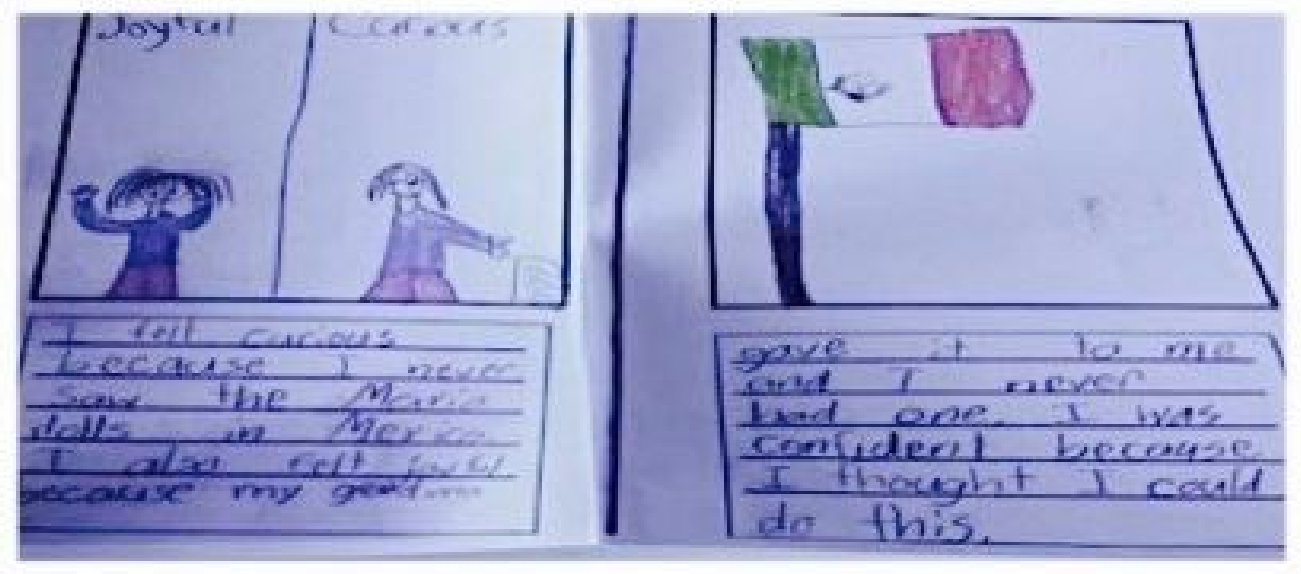

Figure 7. Student sample of target vocabulary in an identity text.

The following is a transcription of Sabina's identity text:

My name treasure is a doll from Mexico. My grandma gave it to me at the airport when I was seven years old. I wanted to share my doll because it is from my culture and from Mexico. I felt curious because I never saw the Maria dolls in Mexico. I also felt joyful because my grandma gave it to me and I never had one. I was confident because I thought I could do this. It is from Mexico and it is unique and special to me because the colours are from the Mexican colours, and I love my Maria doll. 
Author's Page: My name means Special and its origin is Greek. I can speak in English and Spanish. I like to play baseball with my dad and hockey with my dad and Minecraft. (Sabina)

In her identity text, Sabina shared a doll given to her by her grandmother in Mexico before coming to Canada. She was born in Mexico and had been in Canada for 3 years when she participated in the literacy intervention. In learning that her name means special and is of Greek origin, she chose to share something she considered special to her. Sabina explained why she considers her Maria doll a treasure by writing that she had never seen the dolls before in Mexico and now has one that her grandmother, a significant person in her life, gave to her. Sabina also used and applied the target vocabulary in her writing to show her understanding of the words culture, curious, joyful, confident, unique, special, and origin. Of interest is how she used the word confident in her text: "I was confident because I thought I could do this." This phrase captures Sabina's assessment of her own learning and how she felt she had the confidence to complete this learning task.

The preservice teachers also captured the positive impact the literacy intervention had on affirming the students' identity through their lesson reflections. One preservice teacher said,

The most successful part of this lesson was seeing how each of the girls felt very positively about sharing all their artifacts and were proud to share them with each other. I felt that the artifacts that they chose were very useful in aiding their understanding of some of the vocab such as culture, value, customs, and tradition. Sabina mentioned Mexico a number of times in her story. Both of my buddies also really enjoyed filling out the "about the author" page. I think part of this was the ownership but also the accomplishment and pride. (Helen)

Another preservice teacher wrote,

The "name" lesson was the lesson they [the ELLs] were the most engaged with because it actually pertained to themselves. They were engaged when we were talking about it and took it home and talked to their parents around it. They were really excited to come back and share their name treasures. (April)

These preservice teacher quotes reveal the power of lessons that focus on ELL identity and the pride the students feel as they share about their families, languages, and cultures. The creation of the identity texts also supported the ELLs' vocabulary development as they incorporated their target words into their work in meaningful ways. One of the ELLs shared what he learned in the project by stating, "I learned that sometimes people can take things away, but they can't take away your name" (Janat). Another described her learning 
in the project by adding, "I learned to not be afraid of being proud of your name" (Nehi).

\section{Discussion and Implications}

These data provide insight into the positive impact the literacy intervention had on supporting the linguistic and cultural needs of the young ELLs. For educators to cultivate literacy engagement, we need to create a learning space where students can share their stories to affirm their identities. The guiding design principles also focused on intentional and rich task design to support vocabulary development.

\section{Sharing Our Stories: Affirmation of Identity}

The Name Jar Project provided both choice and voice to the ELLs as they explored how they made meaning of their names and created their identity texts. The inquiry questions posed in the intervention provided strong curricular connections and opportunities to affirm the students' identity. The creation of identity texts reinforced the literature as a meaningful and practical way for students to use their knowledge in making meaning of who they are and to see their identities reflected in a positive light in the classroom. Using the power of identity texts, "students can showcase their intellectual, literary, artistic and multilingual talents in ways that challenge the devaluation of their cultures and identities in the school and wider society" (Cummins \& Early, 2011, p. 145; see also Cummins et al., 2015; Stille \& Prasad, 2015).

One of the most successful aspects of the intervention was students' use of the name artifacts to share their stories about their diverse languages and cultures with their peers, teachers, and parents. The students represented their learning through choosing various artifacts that reflected the complex, multilayered, and dynamic identities (Norton, 2006) of ELLs as they make meaning of who they are and navigate their schooling experiences. It is important for educators to continue to reflect on how to affirm students' identity in their instructional design through accessing culturally relevant text, embedding dual language opportunities, and sharing creative task design to be responsive to the linguistic and cultural diversity in classrooms.

\section{Intentional and Rich Task Design: Support Academic Language}

A purposeful focus on tiered vocabulary, and, in particular, Tier 2 words, allows teachers to be more intentional in how they identify vocabulary in lessons and how they can extend academic language through strategies and resources. The Name Jar (Choi, 2001) was a culturally relevant text at an accessible reading level, but the preservice teachers needed to provide supplemental materials and resources to extend students' vocabulary development. The vocabulary pyramid created for this intervention provides an effective 
exemplar for educators in identifying tiered vocabulary within texts to develop and extend academic vocabulary. The design of the intervention invited students to use the target vocabulary in relevant ways as they created their identity texts. Through this meaningful social activity, the students were more invested in their language learning (Norton, 2013) as they were encouraged to use their linguistic, cultural, and experiential assets to support their academic language. When learners are invested in the language practices of the classroom, they are also invested in their own social identity, which supports their language learning (Norton, 2013).

\section{Limitations and Directions for Future Research}

One of the limitations of the small-scale study was the amount of time we were able to allocate to the literacy sessions. Due to the service learning expectations for the preservice teachers, they were limited to $20 \mathrm{hr}$ of contact time with the ELLs. More instructional time to support the conceptual and linguistic objectives of the literacy sessions would have been ideal. Many of the preservice teachers reflected that they felt they needed more time to work with the target words and to differentiate the lessons for the Grade 2 and 3 students. Implementing the intervention again with more time for the literacy sessions would provide preservice teachers with opportunities to go deeper into the lesson concepts and to further develop the target vocabulary.

The intention of this research was to design and implement the Name Jar Project with a purposeful sample of Grade 2 and 3 ELLs with intermediate English proficiency according to provincial ESL benchmarks (Alberta Education, 2012) in small group configurations. A recommendation for future research is to implement the intervention in a linguistically and culturally diverse mainstream classroom with all students. The design principles and the curriculum framework guiding the literacy sessions in the study would be worthy of exploration in the larger classroom setting to explore identity affirmation and support students' vocabulary development.

\section{Conclusion}

My intent in this article was to describe how the Name Jar Project was successful in supporting the needs of the young ELLs. It provided a learning space for students to invest in their language learning and see their identities reflected in a positive light through the creation of their identity texts. The intentional and purposeful focus on the targeted vocabulary supported the ELLs' vocabulary development, and the identity text transcriptions illustrated how the students used the target vocabulary meaningfully and in context to proudly share their stories about their families, languages, and cultures. I hope that this article provides opportunities for educators to reflect on the design principles that guided the project and consider how literacy in- 
terventions such as the Name Jar Project could be used to continue to support ELLs in our diverse multilingual and multicultural learning spaces.

\section{Acknowledgements}

I would like to thank and dedicate this article to my co-researchers: the young students and preservice teachers who inspired me every day during the research project. Congratulations! I'm grateful to the editors of TESL Canada Journal and especially to Editorial Assistant Michael Karas for their guidance and generous support in preparing the manuscript for publication. To the anonymous reviewers, thank you very much for your feedback and mentorship through this process.

\section{The Author}

Theodora Kapoyannis is a sessional instructor in the Werklund School of Education at the University of Calgary. She was a learning specialist with the Calgary Board of Education and completed her PhD at the University of Calgary in 2018. Research interests include design-based and action research, language learning, multiliteracies, and preservice education.

\section{References}

Alberta Education. (2012). Supporting English language learners: Programming information. Retrieved from http://www.learnalberta.ca/content/eslapb/programminginformation.html

Alberta Teachers' Association. (2014). PD survey 2014: A retrospective in brief. Retrieved from https://www.teachers.ab.ca/SiteCollectionDocuments/ATA/Publications/ProfessionalDevelopment/PD-183\%20PD\%20Survey\%202014_2015-07_Web.pdf

Amiel, T., \& Reeves, T. C. (2008). Design-based research and educational technology: Rethinking technology and the research agenda. Educational Technology and Society, 11(4), 29-40. Retrieved from https://s3.amazonaws.com/academia.edu.documents/40540810/ Design-Based_Research_and_Educational_Te20151201-19619-1nc8vxc.pdf?AWSAccessKe yId=AKIAIWOWYYGZ2Y53UL3A\&Expires $=1511059923 \&$ Signature $=$ qhOUMHgXiD5KCS gEak2rFi66OMA\%3D\&response-content-disposition =inline\%3B\%20filename\%3DDesignbased_research_and_educational_te.pdf

Anderson, T., \& Shattuck, J. (2012). Design-based research: A decade of progress in education research? Educational Researcher, 41, 16-25. https://doi.org/10.3102/0013189X11428 813

August, D., Carlo, M., Dressler, C., \& Snow, C. (2005). The critical role of vocabulary development for English language learners. Learning Disabilities Research and Practice, 20(1), 50-57. Retrieved from http://onlinelibrary.wiley.com/doi/10.1111/j.1540-5826.2005.00120.x/abstract August, D., \& Hakuta, K. (Eds.). (1998). Educating language minority children. Washington, DC: National Research Council, Institute of Medicine, National Academy Press.

Banks, J. A., \& Banks, C. A. M. (1997). Multicultural education: Issues and perspectives (3rd ed.). Needham Heights, MA: Allyn \& Bacon.

Beck, I. L., McKeown, M. G., \& Kucan, L. (2002). Bringing words to life: Robust vocabulary instruction. New York, NY: Guilford Press.

Beck, I. L., McKeown, M. G., \& Kucan, L. (2008). Creating robust vocabulary. New York, NY: Guilford Press.

Benson, C. (2013). Towards adopting a multilingual habitus in educational development. In C. Benson \& K. Kosonen (Eds.), Language issues in comparative education (pp. 283-299). Rotterdam, The Netherlands: Sense. 
Biemiller, A. (2004, Spring). Oral comprehension sets the ceiling on reading comprehension. American Educator. Retrieved from http://www.aft.org/newspubs/periodicals/ae/spring2003/ hirschsboral.cfm

Brown, A. (1992). Design experiments: Theoretical and methodological challenges in creating complex interventions in classroom settings. The Journal of the Learning Sciences, 2(2), 141-178. Retrieved from http://www.tandfonline.com/doi/abs/10.1207/s15327809jls0202_2

Choi, Y. (2001). The name jar. New York, NY: Dragonfly Books.

Chow, P., \& Cummins, J. (2003). Valuing multilingual and multicultural approaches to learning. In S. R. Schecter \& J. Cummins (Eds.), Multilingual education in practice: Using diversity as a resource (pp. 32-61). Portsmouth, NH: Heinemann.

Collier, V. P. (1995a). Acquiring a second language for school: Directions in language and education (Vol. 1). Washington, DC: National Clearinghouse for Bilingual Education.

Collier, V. P. (1995b). Promoting academic success for ESL students: Understanding second language acquisition for school. Jersey City, NJ: New Jersey Teachers of English to Speakers of Other Languages-Bilingual Education.

Cope, B., \& Kalantzis, M. (2009). “Multiliteracies": New literacies, new learning. Pedagogies: An International Journal, 4, 164-195. https://doi.org/10.1080/15544800903076004

Coste, D., Moore, D., \& Zarate, G. (2009). Plurilingual and pluricultural competence: Studies towards a common European framework of reference for language learning and teaching. Strasbourg, France: Council of Europe Publishing.

Cummins, J. (1981). Age on arrival and immigrant second language learning in Canada: A reassessment. Applied Linguistics, 2, 132-149. https://doi.org/10.1093/applin/11.2.132

Cummins, J. (1996). Negotiating identities: Education for empowerment in a diverse society. Ontario, CA: California Association for Bilingual Education.

Cummins, J. (2000). Language, power and pedagogy: Bilingual children in the crossfire. Clevedon, England: Multilingual Matters.

Cummins, J. (2011a). Literacy engagement: Fueling academic growth for English learners. The Reading Teacher, 65(2), 142-146. https://doi.org/10.1002/TRTR.01022

Cummins, J. (2011b). Putting the evidence back into evidence-based policies for underachieving students. Strasbourg, France: Council of Europe.

Cummins, J., \& Early, M. (Eds.). (2011). Identity texts: The collaborative creation of power in multilingual schools. Sterling, VA: Trentham Books.

Cummins, J., Hu. S., Markus, P., \& Montero, M. K. (2015). Identity texts and academic achievement: Connecting the dots in multilingual school contexts. TESOL Quarterly, 49(3), 555-581. https://doi.org/10.1002/tesq.241

Cummins, J., \& Man, E. Y.-F. (2007). Academic language: What is it and how do we acquire it? In J. Cummins \& C. Davison (Eds.), International handbook of English language teaching (vol. 2; pp. 797-810). https://doi.org/10.1007/978-0-387-46301-8

Dickinson, D., Flushman, T., \& Freiberg, J. (2009). Vocabulary, reading and classroom supports for learning. In B. Richards, M. Daller, D. Malvern, P. Meara, J. Milton, \& J. Treffers-Daller (Eds.), Vocabulary studies in first and second language acquisition: The interface between theory and application (pp. 23-38). New York, NY: Palgrave Macmillan.

Early, M., \& Yeung, C. (2009). Producing multimodal picture books and dramatic performances in core French: An exploratory case study. Canadian Modern Language Review, 66(2). https:// doi.org/10.10.3138/cmlr.66.2.299

Escamilla, C. (2009). English language learners: Developing literacy in second-language learners: Report on the national literacy panel on language-minority children and youth. Journal of Literacy Research, 41(4), 432-452. https://doi.org/10.1080/108629 60903340165

Freeman, Y., \& Freeman, D. (2004). Connecting students to culturally relevant texts. Urbana, IL: National Council of Teachers of English. Retrieved from http://s3.amazonaws.com/scschoolfiles/819/personalizing_literacy-culturallyrelevantreadings.pdf 
Gee, J. P. (1996). Social linguistics and literacies: Ideologies in discourses (2nd ed.). New York, NY: Falmer.

Gogolin, I. (2002). Linguistic and cultural diversity in Europe: A challenge for educational research and practice. European Educational Research Journal, 1(1), 123-138. https://doi. org.10.2304/eerj.2002.1.1.3

Goldenberg, C. (2013, Summer). Unlocking the research on English learners: What we knowand don't know-about effective instruction. American Educator, 4-38. Retrieved from https://dataworks-ed.com/wp-content/uploads/2016/05/Goldenberg.pdf

Gordon, G. (2009). Toward a pragmatic discourse on constructivism: Reflections on lessons from practice. Educational Studies, 45(1), 39-58. https://doi.org/10.1080/00131940802546894

Guthrie, J. T. (2004). Teaching for literacy engagement. Journal of Literacy Research, 36(1), 1-29. https://doi.org/10.1207/s1554848430jlr3601_2

Hart, B., \& Risley, T. (1995). Meaningful differences in the everyday experience of young American children. Baltimore, MD: Paul H. Brookes.

Horst, M. (2010). How well does teacher talk support incidental vocabulary acquisition? Reading in a Foreign Language, 22(1), 161-180. Retrieved from http://www2.hawaii.edu/ readfl/rfl/ April2010/articles/horst.pdf

Howard Research \& Management Consulting. (2006). A review of K-12 ESL education in Alberta: Study synopsis. Retrieved from https://archive.education.alberta.ca/media/353506/review_of_ esl_study_synopsis.pdf

Howard Research \& Management Consulting. (2009). Kindergarten to Grade 12 English as a second language literature review update. Retrieved from http://education.alberta.ca/media/1182477/ esl_lit_review.pdf

International Literacy Association. (2017). What's hot in literacy: 2017 report. Retrieved from https://www.literacyworldwide.org/docs/default-source/resource-documents/whats-hot2017-report.pdf?sfvrsn=4

Krashen, S. (1981). Second language acquisition and second language learning. Retrieved from http:// www.sdkrashen.com/content/books/sl_acquisition_and_learning.pdf

Linan-Thompson, S., \& Vaughn, S. (2007). Research-based methods of reading instruction for English Language Learners: Grades K-4. Alexandria, VA: Association for Supervision and Curriculum Development.

Lincoln, Y. S., \& Guba, E. G. (1985). Naturalistic inquiry. Newbury Park, CA: Sage.

Lindsay, J. (2010). Children's access to print material and education-related outcomes: Findings from a meta-analytic review. Naperville, IL: Learning Point Associates.

McKenney, S., \& Reeves, T. C. (2012). Conducting educational design research. Florence, KY: Taylor and Francis.

McLaughlin, B. (1992). Myths and misconceptions about second language learning: What every teacher needs to unlearn. Retrieved from http://citeseerx.ist.psu.edu/viewdoc/download;jsessionid=B 2B62EF5B30FBA52EF6088A355A0FB48?doi=10.1.1.575.9354\&rep=rep1\&type=pdf

Naqvi, R., McKeough, A., Thorne, K., \& Pfitscher, C. (2012). Dual language books as an emergent literacy resource: Culturally and linguistically responsive teaching and learning. Journal of Early Childhood Literacy, 13(4), 501-528. https://doi.org/10.1177/1468698412442886

New London Group. (1996). A pedagogy of multiliteracies: Designing social futures. Harvard Educational Review, 66, 6-92. https://doi.org/10.7763/haer.66.1.17370n67v22j160u

Norton, B. (2006). Identity as a sociocultural construct in second language education. In K. Cadman \& K. O'Regan (Eds.), TESOL in context [Special Issue], 22-33. Retrieved from http:// faculty.educ.ubc.ca/norton/Norton\%202006\%20in\%20Australia\%20TESOL.pdf

Norton, B. (2013). Identity and language learning: Extending the conversation (2nd ed.). Clevedon, England: Channel View.

Ntelioglou, B., Fannin, J., Montanera, M., \& Cummins, J. (2014). A multilingual and multimodal approach to literacy teaching and learning in urban education: A collaborative inquiry proj- 
ect in an inner city elementary school. Frontiers in Psychology, 5. Retrieved from http://www. ncbi.nlm.nih.gov/pmc/articles/PMC4062072/

Onwuegbuzie, J. A., Dickinson, W. B., Leech, N. L., \& Zoran, A. G. (2009). A qualitative framework for collecting and analyzing data in focus group research. International Journal of Qualitative Methods, 8(3), 1-21. https://doi.org/10.1177/160940690900800301

Pahl, K., \& Rowsell, J. (2010). Artifactual literacies: Every object tells a story. New York, NY: Teachers College Press. https://doi.org/10.1080/00220671.2012.654754

Parry, K. W. (2004). Constant comparison. In M. S. Lewis-Beck., A. Bryman, \& T. Futing Liao (Eds.), The Sage encyclopedia of science research methods (pp. 181-182). Thousand Oaks, CA: Sage.

Roessingh, H. (2010a). Learning by design. Retrieved from http://esllearningbydesign.com/

Roessingh, H. (2010b). Vocabulary profiling of oral and written discourse: An assessment tool for working with ELLs K-12. Teaching English Language Learners: Paths to Success: Number 5 in a Series of Monographs, 417-441. https://doi.org/10.1007/s12134-011-0202

Roessingh, H. (2011). Family treasures: A dual-language book project for negotiating language, literacy, culture and identity. The Canadian Modern Language Review, 67(41), 123-148. https:// doi.org/10.3138/cmlr.67.1.123

Roessingh, H. (2018). Unmasking the early language and literacy needs of ELLs: What K-3 practitioners need to know and do. BC Teal Journal, 3(1), 22-36. Retrieved from https://ojs-o. library.ubc.ca/index.php/BCTJ/article/view/276/311

Roessingh, H., \& Douglas, S. (2013). Raising the lexical bar: The potential of teacher talk to support learning academic vocabulary. In M. Cowart \& G. Anderson (Eds.), Teaching and learning in diverse schools (pp. 99-124). Denton, TX: The Federation of North Texas Universities.

Roessingh, H., \& Elgie, S. (2009). Early language and literacy development among young ELLs: Preliminary insights from a longitudinal study. TESL Canada Journal, 26(2), 25-45. https:// doi.org/10.18806/tesl.v26i2.413

Roessingh, H., \& Kover, P. (2003). ESL learners' acquisition of cognitive academic language proficiency: What can we learn from achievement measures? TESL Canada, 21(1), 1-21. https:// doi.org/10.18806/tesl.v21i1.271

Schecter, S., \& Cummins, J. (2003). Multilingual education in practice: Using diversity as a resource. Portsmouth, NH: Heinemann.

Statistics Canada. (2017, January 25). A look at immigration, ethnocultural diversity and language in Canada up to 2036, 2011 to 2036. The Daily. Retrieved from http://www.statcan. gc.ca/daily-quotidien/170125/dq170125b-eng.pdf

Stille, S., \& Prasad, G. (2015). "Imaginings": Reflections on plurilingual students' creative multimodal works. TESOL Quarterly, 49(3), 608-621. https://doi.org/10.1002/tesq.240

Strauss, A., \& Corbin, J. (1998). Basics of qualitative research: Techniques and procedures for developing grounded theory. Thousand Oaks, CA: Sage.

Street, B. V. (2003). "What's 'new' in new literacy studies?" Critical approaches to literacy in theory and practice. Current Issues in Comparative Education, 5, 77-91. Retrieved from https:// www.tc.columbia.edu/cice/pdf/25734_5_2_Street.pdf

Taylor, S. K. (2010). The caste system approach to multilingual education in Canada: Linguistic and cultural minority children in French immersion. In T. Skutnabb-Kangas, R. Phillipson, A. K. Mohanty, \& M. Panda (Eds.), Social justice through multilingual education (pp. 177-198). Clevedon, England: Multilingual Matters.

Teaching English to Speakers of Other Languages. (2010). Position paper on language and literacy development for young English language learners (ages 3-8). Retrieved from http://www.tesol. org/doc/pdf/371.pdf?sfvrsn=2

Toohey, K., \& Dagenais, D. (2010). Scribjab. Retrieved from http://www.scribjab.com/ 


\section{Appendix A: Curricular Framework}

Title: The Name Jar: How do we make meaning of our names? Target Group: Grades 2/3 Intermediate English Language Learners.

Broad Goals: Develop curricular concepts, academic vocabulary, strategies, and skills through engaging tasks/ storytelling within the context of The Name Jar. 


\begin{tabular}{|c|c|c|c|}
\hline \multicolumn{3}{|c|}{ Core Objectives } & \multirow{2}{*}{$\begin{array}{l}\text { Lesson Name and } \\
\text { Overview }\end{array}$} \\
\hline Strategies & Language & Concepts & \\
\hline \multirow{4}{*}{$\begin{array}{l}\text { Brainstorming/webbing } \\
\text { Peer work } \\
\text { Cooperative learning } \\
\text { Note taking } \\
\text { Identifying key vocabulary }\end{array}$} & \multirow{2}{*}{$\begin{array}{l}\text { Vocabulary clusters: } \\
\text { Feelings, family, } \\
\text { community, } \\
\text { accepting, affirming } \\
\text { similarities, differences } \\
\text { diversity }\end{array}$} & \multirow{4}{*}{$\begin{array}{l}\text { Identity, naming, } \\
\text { properties and attributes } \\
\text { of people, feelings } \\
\text { Cultural universals: } \\
\text { Naming } \\
\text { Individual uniqueness } \\
\text { Relationships and family } \\
\text { history, tradition } \\
\text { Respecting differences }\end{array}$} & $\begin{array}{l}\text { 1. Getting to know one } \\
\text { another: Learner profile } \\
\text { questionnaire-The } \\
\text { Name Jar game }\end{array}$ \\
\hline & & & $\begin{array}{l}\text { 2. My name ... First } \\
\text { language and culture } \\
\text { connections/traditions. } \\
\text { The meaning of our } \\
\text { names }\end{array}$ \\
\hline & \multirow[t]{2}{*}{$\begin{array}{l}\text { Functions: describe, } \\
\text { explain, summarize, } \\
\text { suggest, analyze, } \\
\text { evaluate, connect }\end{array}$} & & $\begin{array}{l}\text { 3. Family dynamic/ } \\
\text { language use visual } \\
\text { representation, } \\
\text { relationships-scaffold } \\
\text { writing }\end{array}$ \\
\hline & & & $\begin{array}{l}\text { 4. The Name Jar book: } \\
\text { Storybook reading; } \\
\text { feelings: vocabulary }\end{array}$ \\
\hline \multirow{3}{*}{\multicolumn{3}{|c|}{$\begin{array}{l}\text { The Name Jar storybook; other culturally re } \\
\text { Treasure box } \\
\text { Models, writing frames } \\
\text { Word play cards } \\
\text { Name Jar for target vocabulary } \\
\text { Feelings icon sheet } \\
\text { Template for family dynamic/language use } \\
\text { Semantic features analysis matrix } \\
\text { Scribjab website } \\
\text { D2L site }\end{array}$}} & $\begin{array}{l}\text { 5. Name artifacts/ } \\
\text { treasures; LEA }\end{array}$ \\
\hline & & & $\begin{array}{l}\text { 6. What is important to } \\
\text { me-descriptive and } \\
\text { procedural writing; other } \\
\text { storybook reading }\end{array}$ \\
\hline & & & $\begin{array}{l}\text { 7. I'm unique: identify } \\
\text { topics, drawing, } \\
\text { writing; matrix scaffold; } \\
\text { exploration of Scribjab }\end{array}$ \\
\hline & & & $\begin{array}{l}\text { 8. We are a community o } \\
\text { learners: universals that } \\
\text { bring us together }\end{array}$ \\
\hline & & & $\begin{array}{l}\text { 9. Preparing to share our } \\
\text { identity texts }\end{array}$ \\
\hline & & & $\begin{array}{l}\text { 10. Sharing with our } \\
\text { community-celebration } \\
\text { of project }\end{array}$ \\
\hline \multicolumn{2}{|c|}{$\begin{array}{l}\text { Learning Tasks } \\
\text { Exploring the meaning of names through name artifacts (treasures) } \\
\text { Shared reading of The Name Jar, feelings words } \\
\text { Storytelling: sharing stories } \\
\text { Representing information about family dynamic--descriptive writing/ } \\
\text { language awareness and use } \\
\text { Recycling and development of vocabulary through word play cards/ } \\
\text { name jar } \\
\text { Recording sources of information/references } \\
\text { Making notes } \\
\text { Exploration of first language through Scribjab website (http://www. } \\
\text { scribjab.com/), a digital story/multiple languages technology tool }\end{array}$} & \multicolumn{2}{|c|}{$\begin{array}{l}\text { Assessment Strategies } \\
\text { Completion of task cards } \\
\text { Scaffolded activities } \\
\text { Vocabulary measures (both informal and formal) } \\
\text { Writing samples } \\
\text { Student self-assessment of target words/word jar }\end{array}$} \\
\hline
\end{tabular}

Note. ELLs = English language learners; D2L = Desire2Learn; ELA = English language arts; LEA = language experience approach. 


\section{Appendix B: Strategies for Working With the Word Play Cards}

Each student will have his or her own personalized word play cards. Provide gaming opportunities at each literacy session and encourage students to create their own games. Word play cards are an important resource in learning and automatizing vocabulary knowledge. You can make them in a variety of ways and use them for word play, review, and as a tangible reminder to the students that they are acquiring many words.

\section{Making the Word Play Cards}

1. Print the word on one side and the definition on the back side.

2. Add the translation into the first language (if applicable) on the front or back side.

\section{Word Play Ideas}

\section{Scatter the Cards on the Table (8-10 Cards)}

- Teacher says the word; student picks up the card. This establishes word recognition, often on phonics information.

- Teacher gives a definition; student picks up the card. This displays a deeper understanding of the vocabulary.

- Student says the word; other students pick up the card.

- Student gives a definition; other students pick up the card.

Leave the Cards on the Table

- See if the students can complete a crossword puzzle using the available words.

Play Games

- Play charades: Students draw a random word out of the name jar and play charades, acting out the word on the card for their peers to guess.

- Recycling games: Play Go Fish, create a bingo game, or complete a crossword to recycle the words.

- Version of Hedbanz! Get the kids moving! Give a student a word to put on his or her forehead (without knowing what the word is). The student asks the other students and teacher for clues: For example, What is a synonym for my word? What does my word rhyme with? Where is a place I might find my word? What is the opposite of my word? The student then guesses what the word is: For example, "I think my word is . ..." Teachers will need to model this game with the students.

- What's my word? Student has to guess from clues that other students give what the word is: For example, if the word is proud, the other students can give the words feeling, great, humble, accomplish (but cannot say the word proud). This can be timed for a competitive addition.

- Grouping into semantic associations. Have three containers and group the words into the containers. Place all the words on the table and have the students decide which container to put the words into: For example, all the feeling words, examples of name artifacts/treasures, words they see in different languages. Add a timing factor.

\section{Use Resources Available in the Public Domain}

- Kahoot. Review and recycle vocabulary and assess (preassessment, self-assessment, or summative assessment) students' vocabulary development (https://kahoot.com/).

- Scribjab. Create identity texts using this multilingual digital storytelling app (http://www.scribjab.com/). 